\title{
French ministry reopens inquiry into conduct of INSERM unit
}

[PARIS] France's ministry of national education, research and technology is to reopen an inquiry into the activities of a laboratory of INSERM, the national biomedical research agency, following criticisms by the university at which the laboratory is located - as well as some present and former staff - of the way in which the previous government handled earlier evaluations and investigations.

Controversy centres on claims by the INSERM Laboratory of Nutrition, Lipoprotein Metabolism and Atherosclerosis, based at the University of Rennes 1, to have identified and now cloned a 'lipolysis stimulated receptor', a molecule involved in fat degradation. "As there is a new government we felt we needed to have a fresh look at the matter," says Jacqueline Godet, director of life sciences at the ministry.

INSERM and the French biotechnology company Genset have jointly applied for a patent on the work - which may have implications for obesity research - as part of plans costing FFr60 million (US\$10 million) to build a laboratory for molecular physiology and pathology at a new private university at Ker-Lann near Rennes. The project is being partly financed by local government.

The allegations have come mainly from a

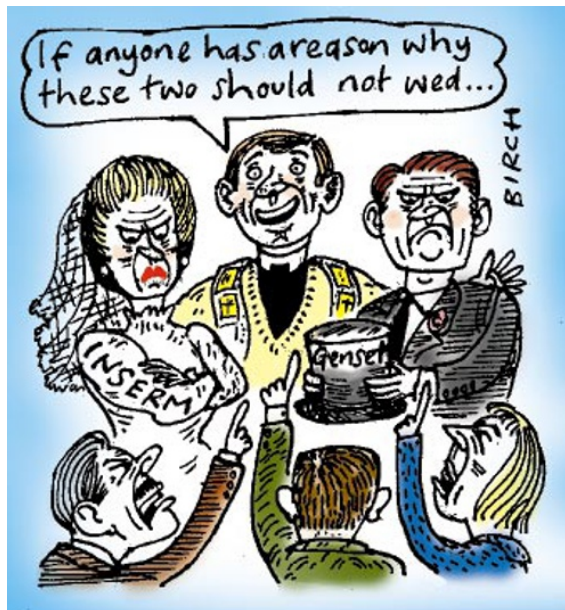

group of more than 20 'whistleblowers' who work or have worked in the laboratory. The group refuse to reveal their identities publicly, although they have done so in confidence to recent inquiries. But Bernard Bihain, the director of the laboratory - and the principal target of the allegations argues that this is unfair, and that it leaves him open to 'score settling' stemming from personal conflicts.

The only relatively detailed exposition of the scientific aspects of the affair available at

\section{Spain blocks new Framework programme}

[MUNICH] The smooth continuation of the European Union (EU)'s five-year Framework programmes of research is being held hostage for the first time to broader political considerations. At a meeting of representatives of member states in Brussels last week, Spain - supported by Portugal - refused to vote on the proposals for the fifth Framework programme (FP5), due to start next year.

Spain is trying to use its veto power to force member states to continue to give it large amounts of structural funds subsidies given to poorer EU countries and regions. Because the Framework programme must be approved unanimously by the Council of Ministers, which represents the member states, the result of Spain's action could be a gap in funding for researchers, as the fourth Framework programme (FP4) ends next December.

The EU has been required to rethink the way in which it distributes its structural funds because of its planned enlargement within the next decade to include some eastern European countries. Last summer, the European Commission published
Agenda 2000, an informal communication covering the period $2000-06$, proposing that, to make structural funds available to the newcomers before joining, spending on current members should not increase in nominal terms.

This means considerable real-term losses in income for major beneficiaries such as Spain, which is depending on these funds to maintain its economic criteria for joining full European monetary union. The threat to EU-funded research comes from the fact that Agenda 2000 will not be debated before the end of this year.

EU research ministers have their last chance next week to approve a common position, if FP5 is to start on schedule. Attempts are being made to persuade Spain to drop its blocking action. Its toughest opponent will be Germany, which strongly supports the move to divert structural funds to help future EU members that it borders, such as Poland and the Czech Republic. Germany opposes an increase in the overall budget to allow current beneficiaries to enjoy the level of subsidies to which they have become accustomed.

Alison Abbott present is a report commissioned by the university from Michel Philippe, a researcher at the Centre National de la Recherche Scientifique laboratory of biology and genetics of development at the University of Rennes 1. The report, submitted in December to Jacques Lenfant, the president of the university, describes difficulties in "reconciling" results concerning the molecular weights of candidate clones of the receptor and its antibody reactivity.

Analysis of the allegations is complicated by the fact that the University of Rennes 1, which has demanded a broader investigation of the laboratory, is in dispute with INSERM over the terms of the industrial joint venture. Lenfant claims the university was not consulted on the initiative and was omitted from the patent applied for jointly by INSERM and Genset. INSERM "failed to respect" its contract with the university, he says.

Bihain claims that he is caught in a conflict between the university and INSERM over the patent. He denies any wrongdoing, and criticizes the inquiries for not allowing him due process, saying "I have never been given the opportunity to clear my name." He also argues that, even if exonerated, suspicion will inevitably be cast upon his work.

But Lenfant claims the importance of the industrial venture, under which Genset has worldwide rights to licences on any patents, with INSERM sharing royalties, may have influenced past investigations. The deal, announced last February, was described then by Pascal Brandys, Genset's chief executive officer, as "instrumental in expediting our massive search for disease susceptibility genes." INSERM's director general, Claude Griscelli, called it an example of the "policy of industrial partnerships that INSERM wishes to reinforce".

Lenfant claims that evidence of pressure to protect these interests comes from the circumstances surrounding a vote in Mayby the INSERM committee responsible for the routine evaluation of Bihain's laboratory, which narrowly approved - by 13 votes out of 25 - renewal of the laboratory.

Before the vote Griscelli emphasized to the meeting the importance to INSERM of pursuing the industrial partnership. Critics say that this constituted a form of pressure on the committee. This was "abnormal", says Lenfant, arguing that it is "astonishing that a director general should intervene at this level".

Jean-Claude Stoclet, chairman of the commission, denies that it was improper for Griscelli to say that the agreement exempli- 
fied INSERM's industrial policy. But he accepts that the importance of the industrial venture constituted indirect pressure: "If we had given a negative opinion, we would have been disowning our own institution."

Bihain asserts that it was around this time that he discovered the university was investigating him "without his knowledge", and that he subsequently "telephoned the ministry to seek independent arbitration". In October he filed charges of defamation against Lenfant, although he has now dropped proceedings, understanding the affair to be closed.

On 15 September, Bernard Bigot, then director general of the research ministry, set up a commission of inquiry, chaired by Pierre Corvol of the Collège de France in Paris, which received testimony from more than 20 of the whistleblowers. It submitted its report to the ministry on 28 October.

But the report was never made public, and according to Lenfant the university has itself been unable to obtain a copy, despite a written request to Claude Allègre, the science minister, which he says has gone unanswered.

Jean Rey, an adviser to Allègre, says "we have not excluded [scientific fraud], but we have not established it."

Bihain says he has not seen the Corvol report, but he understands its main conclusions are that additional experiments to verify the identity of the receptor would have been useful. According to Bihain, it also shows that one gel lacked proper molecular weight standards, but he claims that this involved a flawed experiment by a young researcher that was never published.

In written testimony to the Corvol com- mission, Daniel Renou, the INSERM representative in the region until last August, says Bihain treated those who worked for him harshly. "The institute cannot remain deaf to the distress provoked," he wrote.

Renou also submitted evidence of what he claimed were violations of health and safety regulations in the laboratory, and criticized what he describes as Bihain's lack of cooperation on these issues with the authorities. Corvol last week declined to comment on the report, saying only that the affair was "complex".

Controversy also surrounds the fact that the Corvol report was not made available to a meeting of the scientific board of INSERM, at which Bihain's unit was again evaluated, a week after the report was submitted to the ministry. The commission gave a positive decision on the basis of Bihain's presentation, including the fact that a patent had been applied for on his research, and that the results on which this was based had been submitted to a number of scientific journals. But it ruled that the laboratory should be evaluated in two years' time, rather than in four as is usual.

Rose Katz, who chairs the board, says she requested a copy of the Corvol report from Griscelli, but he replied that he did not have one. Katz, who says it would have been "preferable" for the board to have seen the report before ruling on Bihain's laboratory, adds that she has still not been able to see the report. It would have been "more healthy" for this to have been made public, she says.

To complicate matters further, Bigot then carried out his own inquiry, visiting the Rennes laboratory on 28 November and telephoning current and former staff. This second inquiry was needed to "ensure the veracity of the testimonies," says Rey.

Bigot's report, submitted to the ministry on 10 December, cleared the laboratory of misconduct. A summary concludes that "no formal element" refuted the laboratory's research, which, alluding to the industrial interest, Bigot describes as being "on a promising subject that has recently known considerable developments, and which it would be unacceptable to see being abandoned". Nevertheless the report recommends that Bihain "be invited to pay greater attention to his behaviour vis-à-vis his collaborators". (Since 1993, more than 40 staff have left the laboratory or been fired.)

In a letter on 21 January to Daniel Nahon, the new director general of the science ministry, the whistleblowers call for the case to reopened, arguing that the Bigot report fails to take their allegations seriously. The letter - again anonymous, although the signatories' names have been deposited in confidence with Philippe - points out that the Bigot report cites only one paragraph from the Corvol report, stating that "the commission attracts the attention of the minister to the fact that it was convened, by a large number of members and former members of the INSERM unit 391, to consider serious accusations concerning the behaviour of the director of this unit and its scientific activity."

The Philippe report states that some of the laboratory's work poses "many problems". It concludes that "an in-depth analysis carried out by international experts in the field is absolutely necessary."

Declan Butler\& Olivier De Gandt

\section{New Hubble institute chief seeks broader focus and more work}

[WASHINGTON] The institute that manages the science programme for the Hubble Space Telescope (HST) should expand its focus beyond that instrument, according to the director chosen to lead the institute into the next century.

Steven Beckwith, who is to take over the helm at the Space Telescope Science Institute (STScI) in Baltimore, Maryland, next September, says one of his main objectives will be bringing in new work to the institute. "HST is the only thing that's done by the institute, and I personally think that's too little for an institute with the kind of resources that are there," says Beckwith, who is at present managing director of the Max Planck Institut für Astronomie in Heidelberg, Germany.

Beckwith, whose appointment was announced by the Association of Universities for Research in Astronomy last week, succeeds Robert Williams as the institute's third director. A native of

Wisconsin, Beckwith was a member of the astronomy faculty at Cornell University before joining Max-Planck, which he helped turn into a leading astronomy centre. He is an expert on star and planet formation, and has been a principal user of Europe's Infrared Space Observatory.

The most obvious new line of work would be to manage the scientific programme for the planned Next Generation Space Telescope (NGST), an infrared-optimized space observatory that

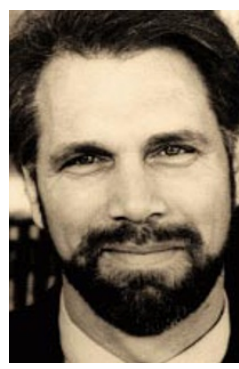

Beckwith: keen for more collaboration. the US National

Aeronautics and Space Administration plans to launch as a successor to Hubble around 2007 (see Nature 389, 651; 1997). The STScI is generally thought to be the leading contender for operating the NGST. But "even that by itself is probably not enough", says Beckwith.

The institute, he says, could be a leader in providing software products, such as those used for data reduction and telescope scheduling, to the general astronomy community. Programs written for the space telescope could be used just as well by other space- and ground-based instruments.

Although some sharing is already going on, he says, the astronomy community has not reached the level of collaboration that he sees among particle physicists. "We don't share as much as we could. It should be possible to save money overall for the field, or at least be able to use the resources we've got to do more than we are, by not duplicating efforts."

This sharing of resources has political problems, he admits, and will happen only if large observatories and astronomy institutions sit down together to "establish a dialogue among the principal actors." Beckwith would like the institute to play a lead role in that dialogue. 